\title{
NOTES ABOUT CHILEAN UREDINALES. VI: UROMYCES TRAUCOENSIS SP. NOV. ON SELLIERA RADICANS CAV. (GOODENIACEAE) AND ITS DISTRIBUTION AREA.
}

\author{
Jaime R. Montealegre A. y Edgar Oehrens B. \\ Depto. Sanidad Vegetal \\ Facultad de Ciencias Agrarias y Forestales. \\ Universidad de Chile. Casilla 1004 - Santiago - Chile
}

SUMMARY

The characteristics of $a$ new autoic and macrocyclic nust (Uromyces traucoensis $n$. sp.) occurring on Selliera radicans Cav. (Goodeniacea) in Chile are described. This rust is very similar to $\mathbf{U}$. sellieriae and $\mathbf{U}$. scaevolae, the former from New Zealand and the latter from New Zealand, Australia and Tasmaria on the same host. The dispersion of Selliera and the three Uromyces species is comprared with that of Uredinales attacking Coniferae, of Cyttraria on Nothofagus, and of Uromyces minor on Trifolium dublum both in Chile and New Zealand.

\section{INTRODUCTION}

According to Cronquist (1981) and Melchior (1964), the fam. Goodeniaceae consisting of 14 genera and 30 species mostly of Australian origin, is also found in New Zealand, Japan and in different tropical and subtropical regions, both in the new and old world. Selliera radicans Cav. belongs to this family and is reported from Australia, New Zealand and Chile. Information from the herbarium of the University of Concepcion, indicates that in Chile this species occurs in saline and swampy coastal lands from Huasco to the Guaitecas Isiands ( $28^{2} 30^{\prime}-44^{2} 0^{\prime}$ ' S.L.).

The first rust record on this plant was recorded in Australia (Mc Alpine, 1906) and New Zealand (Cunningham, 1913) from where two Uromyces species were described: U. sellierlae G.H. Cunn. with 0, II and III, exclusively of New Zealand, and

1 Research project № A $1484-8323$ of the University of Chile's Research and Development Department.

\section{RESUMEN}

Notas sobre Uredinales chilenas. VI: Uromyces traucoensis sp. nov. en Selliera radicans Cav. (Goodeniaceae) y sus áreas de distribución]

Se describen las características de una nueva especie de Uredinal autoico y macrociclico sobre Selliera radicans Cav. (Goodeniaceae) en Chile, al que se le denominó Uromyces traucoensis, estableciéndose semejanzas y diferencias con otras especies de Uromyces que atacan este hospedero en Australia y Nueva Zelandia.

Se comenta la dispersión del hospedero y de las tres especies de Uromyces, correlacionándola con otros casos semejantes, tales como Uredinales que atacan coniferas, el género Cyttaria sobre Nothofagus y el caso de similitud extremadamente coincidente del mismo biotipo de Uromyces minor sobre Trifolium dubium en Chile y Nueva Zelandia.

U. scaevolae G.H. Cunn., widely distributed in eastern and southern Australia, Tasmania, New Zealand with I, II and III.

From Chile no rusts are so far reported occurring on Selliera (Mujica and Vergara, 1980). However, a new rust attacking S. radicans has been recently collected in Gaubún. (Ancud, Chiloé Island).

\section{METHODS}

The first rust material was collected in Gaubún on January 31, 1981 (Table 1), Additional samples were collected from a few other sites from Corral to Quemchi. On May 22, 1982, plants with soil from Gaubún were collected again and cultivated; subsequently microscopic measurements and microphotographies of the different fungal states and mature spores were made (spermogonia $=0$, aecidia $=$ I, uredosori $=$ II and teleutosor $\mathbf{~ = ~ I I I ) . ~}$

Furthermore, histological sections of 
spermogonia, aecidia, uredosori and teleutosori were made with a freezing microtome. From these, spores were also obtained for scanning electron microscopic (SEM) studies according to the methodology pointed out by Latgé et al (1982).

\section{TABLE 1}

Localities where U. traucoensis was collected

\begin{tabular}{|c|c|c|c|}
\hline Locallty & Province & Date & State \\
\hline \multirow[t]{2}{*}{ Gaubún } & Chiloé & 31-I-1981 & $0-I^{*}$ \\
\hline & & $22-V-1982$ & I-II-III \\
\hline Quinterquén & Chiloé & 27 y 29 XII-1982 & 0-I-II-III \\
\hline Corral & Valdivia & 22-II-1983 & II y III \\
\hline
\end{tabular}

- Type material

\section{RESULTS}

\section{Symptomatology}

The first symptoms are chlorotic spots on both leaf surfaces and rarely on petioles. Subsequently, spermogonia (0) and amphigenous aecidia (I) appear on these spots. the Aecidia are orangeyellow; when they occur in great numbers they converge producing leaf elongation and deformation resulting in necrotic tissue and plant defolation. Later, pulverulent reddish-brown amphigenous uredosori (II) develop. On these, teleutospores (III) grow and chlorosis appears around a central sorus. Several sori may converge producing necrosis and defoliation.

\section{Aetiology}

The above mentioned symptoms are caused by an undescribed Uromyces whose measurements and characteristics differ (Tables 2,3) from the two earlier described species on S. radicans (Mc Alpine, 1960; Cunningham, 1923; 1931). We consider this autoecious and macrocyclic rust a new species, Uromyces traucoensis, whose name is derived from the Chilean word "Trauco" (= mythological being).

\section{TABLE 2}

Dimensions of aecio (I) (peridial cells $=$ P.C.), uredo (II) and teleutospores (III) of $\mathrm{U}$. traucoensis*
Spores and walls

I

P.C.

II

Wall

III

Apical wall

Side wall
Dimensions (spore lenght and width, and wall thickness)

\section{* 100 measurements}

Uromyces traucoensis n.sp. is an autoecious and macrocyclic rust whose main characteristics are as follows:

\section{Uromyces traucoensis $\mathbf{n}$. sp.}

Spermogonia amphigena, subepidermata in maculis flavis insidentia, subglobosa, 49.6 (46.150.8) × 45.0 (41.5-46.1) u diam. Aecia epiphylla, sistemica, cupulata, flavoaurantiacea; cellulae peridae inaequaliter rhomboideae, 36.7 (24.4-52.5) x $23.0(15.0-36.0) \mathrm{u}$; aeciosporae catenulatae, late globosae vel ellipsoideae, episporio hyalino vel pallide brunneoflavo, verrucosae, 30.2 (23.4-37.7) $\times$ 24.7 (18.4-31.9) u. Uredinia amphigena, rufobrunnea, sparsa vel circumcincta, $2-3 \mathrm{~mm}$ diam.; urediniosporae globosae vel subglobosae, complanatae, 36.0 (30.4-46.9) × $32.7(26.2-39.8) u$, episporio brunneoflavo, 2.6 (1.9-3.7) u crasso, echinulato circum porum, poris germinativis 2, equatorialibus. Teliosporae per uredinia aggregatae, brunneocastaneae, ovoideae, obovoideae vel subglobosae, $35.6(30.0-43.1)$ x $28.4(21.9-36.2)$ $\mathrm{u}$, pariete pallide flavobrunnea, levi, 1.5-3.0 u crassa ad latere, 3.4-7.1 u crassa ad apicem; pedicellus hyalinus, brevis, fragilis. Typus J. Montealegre, HFV, 31 Jan. 1981 ad folias Selliera radicans Cav. in Gaubún, insula Chiloé (prope Ancud), Chile; isotypi LPS et PUR. 


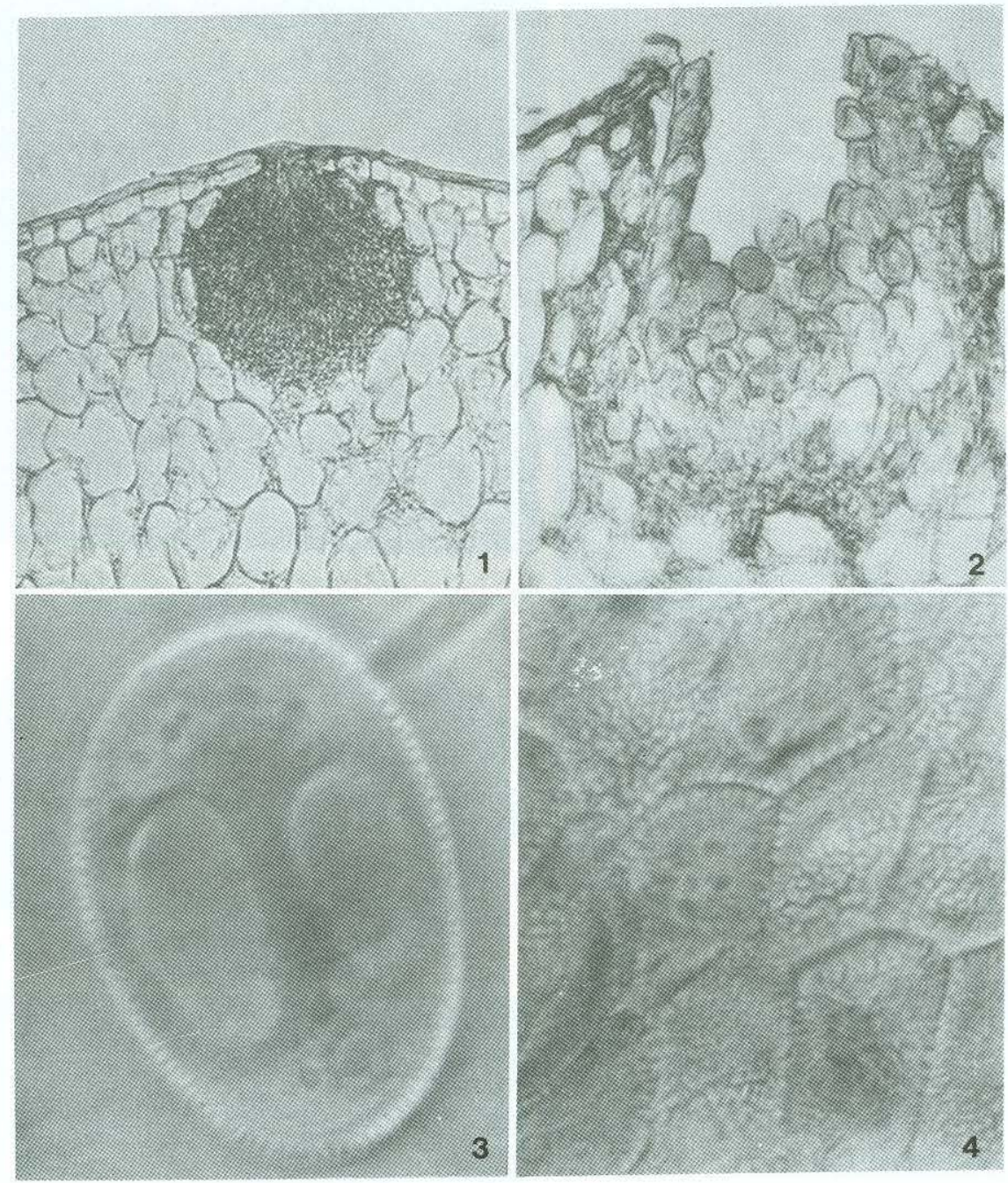

Fig. 1 Uromyces traucoensis, spermogonium (570.9 x). Fig. 2. Aecidium and aeciospores (816.1 x). Fig. 3 Aeciospore $(7777 \mathrm{x})$ Fig. 4. Peridial cells $(2720 \mathrm{x})$. 

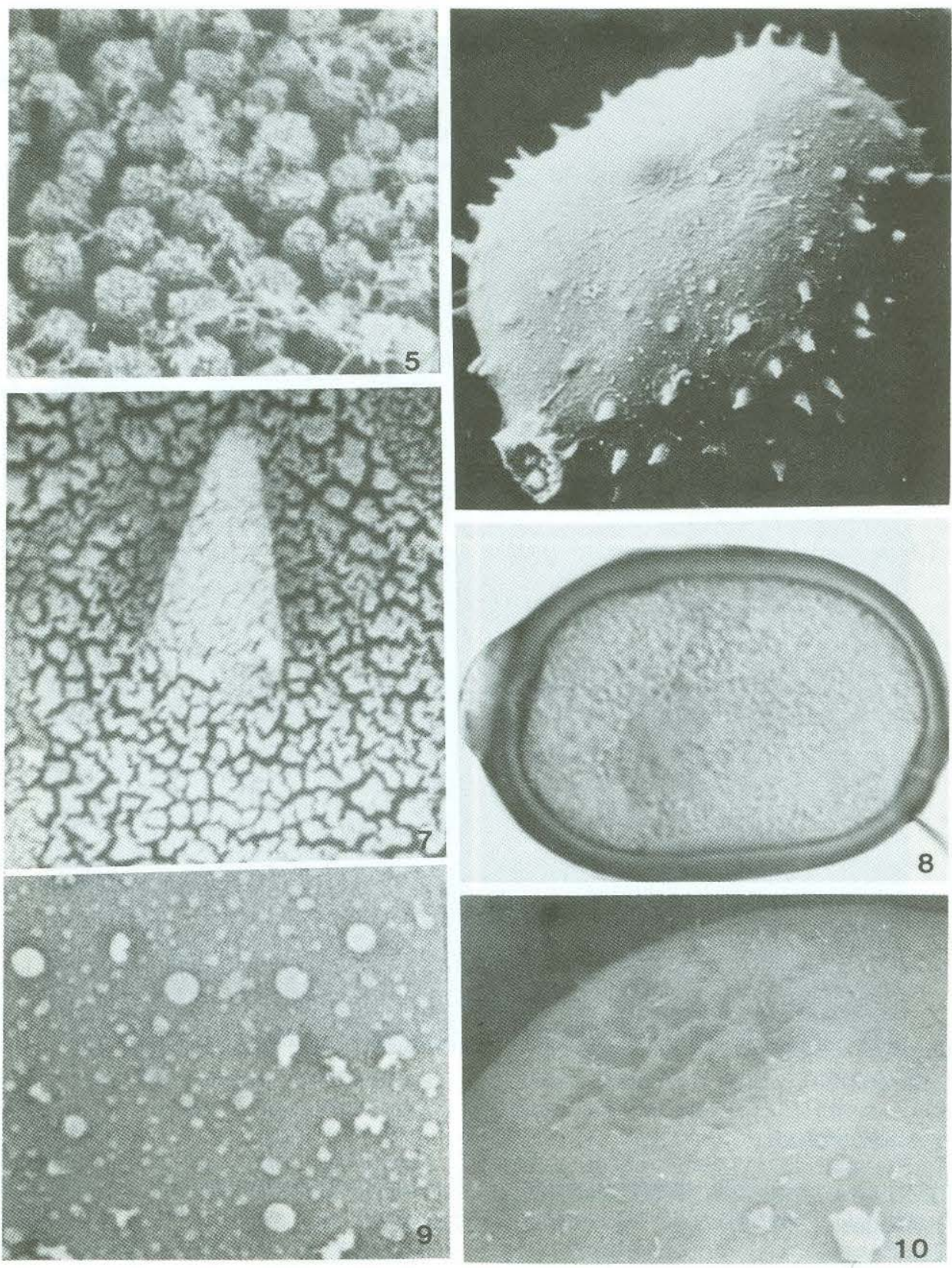

Fig. 5 Aeciospore episporium of U. traucoensis $(17777 \mathrm{x})$. Fig. 6. Uredospore ( $2333 \mathrm{x})$. Fig. 7. Uredospores surface and spinule $(19000 \mathrm{x})$. Fig. 8. Teleutospore $(4779.4 \mathrm{x})$. Fig. 9. Teleutospore surface $(19.000 \mathrm{x})$ Fig. 10. Teleutospore apex $(44461.5 \mathrm{x})$. 


\section{TABLE 3}

\section{Comparative data of three Uromyces species on S. radicans}
U. scaevolae
U. sellieriae
U. traucoensis

Geographical
distribution

States:

\section{I}

II

Side wall

Apical wall

Spores III
Australia, Tasmania, N. Zealand

0 - I - III

$14-20 \times 14$ - 18 um

(localized)

$32-46 \times 18-24$ um

15.0 um

on I

\section{N. Zealand}

Chile

I - II - III

$26-36 \times 18$ - 24 um

(localized)

28 - $35 \times 30$ - 36 um

28 - $35 \times 18$ - 28 um

-

on II
0 - I - II - III

23.4-37.7 x 18.4-31.9 um

(systemic)

30.4-46.9 x 26.2-39.8 um

30.0-43.1 x 21.9-36. $\mathrm{um}$

2.4 um

$5.0(3.4-7.1)$ um

on II
0 Spermogonia subepidermic, amphigenous and almost spheric $46.1-50.8 \times 41.5-46.1 \mathrm{um}$, average $45.0 \times 49.6 \mathrm{um}$, occurring on yellowish chlorotic spots, apparently without periphysis (Fig. 1).

I Systemic aecidia mostly epiphyllous, disperse, orange-yellow with hyaline borders (Fig. 2). Peridial cells with smooth and thinner walls on the outside face but verrucose and thicker, on the inside face; in general, of rhomboidal shape, 24.4-52.5 x 15.0-36.0 um, average $36.7 \times 23.0$ u (Fig. 4). Aeciospores globose to broadly ellipsoid with a hyaline to light yellowish-brown verrucose epispore, 23.4-37.7 $\times 18.4-31.9 \mathrm{u}$, average $30.2 \times 24.7 \mathrm{um}$ (Fig. 3).

II. Uredosori of $2-3 \mathrm{~mm}$, subepidermic, mostly epiphyllous, disperse but frequently concentric to a central sorus, reddish-brown, covered when immature and pulverulent later on. Uredospores globose to subglobose, laterally flattened, $30.4-46.9 \times 26.3-39.8 \mathrm{um}$, average $36.0 \times 32.7$ um (Fig. 6), with yellowish-brown to light-yellow epispore, 1.9 x $3.7 \mathrm{um}$ thick, average $2.6 \mathrm{um}$, spinulose, with two equatorial germinative pores.

III. Teleutospores intermixed in the uredosori, ovoid or subglobose, $30.0-43.1 \times 21.9-36.2$ um, average $35.6 \times 28.4 \mathrm{um}$, chestnut-brown smooth wall with yellowish-brown epispore with a prominent and flattened papilla, 3.4$7.1 \mathrm{um}$, averge $5.0 \mathrm{um}$, localized at the apex or laterally, 1.5-3.0, average 2.0 um; hyaline, short and fragile pedicel (Fig. 8).
The following characteristics are based upon SEM observations: aeciospores with epispore covered with small truncated verrucae, densely agglomerated (Fig. 5); uredospores with the spinules disappearing near the germinative pore (Fig. 6); fissures on the epispore surface with dendritic aspect (Fig. 7); spores flattened on both sides of germ pores (Fig. 6) which hinders the simultaneous observation of both overlapping pores.

Through the light microscope, teleutospores appear as smooth structures; however, in SEM observations they exhibit verruculose unevenly distributed proyections (Fig. 9) and small fissures on the depressed apex of the spores (Fig. 10).

\section{DISCUSSION}

The differences among the three Uromyces species on S. radicans are indicated in Table 3. There, it is observed that $U$. traucoensis differs from $U$. scaevolae in that the former presents all the stages ( 0 - I - II and III) while the latter lacks II. U. sellieriae lacks 0 according to Cunningham (1931). U. traucoensis aecidia are systemic while those of the two other species are localized. Both $U$. traucoensis and $U$. scaevolae, exhibit an apical papilla in their teleutospres, which is larger in the latter species

Aeciospores are larger in $U$. traucoensis than in the other two species; likewise, urodespores are larger in U. traucoensis than in U. sellierae, both with two equatorial germinative pores

Teleutospores in $U$. scaevolae are longer and narrower than those of $U$. sellierae. Also, $U$. 
traucoensis teleutospores are wider than those of U. sellierae, which are of intermediate size. In the three species there are no actual teleutosori, but teleutospores develop in aecia in $\mathbf{U}$. scaevolae and in uredosori in U. sellierae and U. traucoensis.

All these differences indicated us that this Chilean Uromyces would be a new species.

Its should be pointed out that work conducted in New Zealand, from Cunningham (1945) to McKenzie (1981), either adding or correcting information on rusts, did not refer to species attacking Selliera radicans.

The similarity of phanerogamic flora of Chile with that of New Zealand and Australia has been reported by Godley (1960), van Steenis (1962), Schmithusen (1968), Darlington (1969), van Steenis (1971) and Dimitri (1972). Some of them point out the Nothofagus genus as one of the most classic examples of this similarity. In the southern hemisphere, Nothofagus is distributed in the forest regions of the Patagonic Andes of Chile and Argentina, in New Zealand, Tasmania, Australia, New Caledonia and New Guinea. Its dispersion area, except in the two latter islands, is commonly found in association with Cyttaria fungi. Van Steen (1971) also indicates a certain similitude in the Agaricales species forming ectotrophic mycorrhizae in Nothofagus, distribution area an aspect which has recently been discussed by Horak (1983).

With regard to rusts (Uredinales), similarities have been reported in spermogonia and aecia of Mikronegeria alba (on Austrocedrus chilensis), M. Pagi (on Araucaria araucana) and Caeoma peltatum (on Phyllocladus trichomanoides and Ph. glaucus), in Chile and New Zealand (Shaw III, 1976 and Hiratsuka and Hiratsuka, 1980). Both Mikronegeria species develop their dikariotic state on deciduous Nothofagus in the Patagonic Andean forests. The main host for Caeoma peltatum is still unknown.

Cronquist (1981) and Carolin (1978) suggested that Campanulaceae developed mainly in western Gondwana (Southamerica and Africa) Goodeniaceae in Eastern Gondwana (Australasia and Antarctica). Shuster (1976) pointed out that the genus Nothofagus would have evolved in Southamerica and would have moved during the Cretaceous period through the Antarctic bridge westward in relation with the areas where it is presently found. Probably, Selliera radicans has moved in a similar way but in the opposite direction in more recent times. This conclusion is based on the fact that this species occurs in very distant areas and has not reached a differentiation in subregional species of Australia, New Zealand and Chile. However, Uromyces species that today grow on this host over its wide distributional area, are the result of evolution of one primary common ancestral species, This species has evolved till the level fo the three regional species that we mention in this paper.

The identification of this new species of Uromyces on $S$. radicans, with characteristics similar to those of the Australian and New Zealand species, leads us to make a comment of difficult acceptability which is the equality shown by another species of the same Uromyces genus. In November 1966, the occcurrence of Uromyces minor Schroet. on Trifolium dublum Sibth. was recorded for the first time in Valdiva (Oehrens and González, 1972). This same association had already been reported in New Zealand by Laundon (1970). So, the adventiceous host, the parasite, and the year of the first observation coincide in both regions. This notable coincidence was further stressed by the identification of this same Uromyces genus on pea (Pisum sativum L.) in Valdivia (Oehrens and González) at the beginning of 1973. As in the previous case, the infection of this unusual host had also been reported earlier (1971) in New Zealand (Savile, 1979).

Lastly, in addition to the coincidences already pointed out, we would have to add that the Uromyces minor biotype is likely to be the same as that of New Zealand, a hypothesis that should be tested by further studies. Likewise, the causes of these coincidences should also be determined by future investigation.

\section{ACKNOWLEDGMENTS}

The authors gratefully acknowledge the assistance provided by Prof. Victor Monasterio of Departamento de Biología, Facultad de Ciencias, Universidad de Chile, in the SEM observations, Prof. Clodomiro Marticorena of the Departamento de Botánica, Universidad de Concepción and Prof. Ana María Espinoza, Depto. de Producción Agrícola, Facultad de Ciencias Agrarias y Forestales, Universidad de Chile, for rendering this paper into English. 


\section{REFERENCES}

CRONQUIST, A. (1981). An integrated system of classitication of flowering plants. Columbia Univ. Press, 1262 p.

CUNNINGHAM, G.H. (1923). The uredinales or rust fungi of New Zealand. Trans. \& Proc. N.Z. Inst. 54:619-704.

- (1931). The rust fungi of New Zealand. John McIndoe, Dunedin, 261 p.

- (1945). Additions to the rust fungi of New Zealand I. Trans. Roy. Soc. N.Z. 75:324-327.

DARLINGTON, Jr., P.J. (1969). Biogeography of the sourthern end of the world. Harvard Univ. Press, Cambridge (Mass.), 236 p.

DIMITRI, MJ. (1972). La región de los bosques andinopatagónicos. INTA, Col. Cient. X, 381 p.

HORAK, E (1983). Mycogeography in the South Pacific Region: Agaricales, Boletales. Aust. J. Bot. Suppl. Ser. 10: $1-41$. .

HIRATSUKA, Y. and N. HIRATSUKA. (1980). Morphology of spermogonia and taxonomy of rust fungi. Rept. Tottori Mycol. Inst. 18:257-268.

GODLEY, EJ. (1960). The botany of southern Chile in relation to New Zealand and the Subantarctic. Proc. Roy. Soc., B, 152:457-475.

LATGE, J.P.; M.C. PREVOST; D.F. PERRY et $O$. REISINGER. (1982). Etude en microscopie électronique de Conidiobolus obscurus 1. Formation et germination des azygospores. Can Journ. Bot. 60:413431.

LAUNDON, G.F. (1970). Additions to the rust fungi of New Zealand 0 5. N.Z. Journ. Bot. 8: 310-319.

McALPINE, D. (1900). The rust of Australia. R.S. brain, Melbourne, 349 p.
McKENZIE, E.H. (1981). New Zealand rust fungi: additions and corrections. N.Z. Journ. Bot. 19:227-232.

MELCHIOR, H. (ed). (1964). Engler's Syllabus der Planzenfamilien. II. Borntraeger, Berlin (Goodeniaceae: 482-483).

MUJICA, F. y C. VERGARA. (1980). Flora Chilena (2da. ed. rev. y act. por E. Oehrens). Ed Univ., Santiago de Chile, 308 p.

OEHRENS, E. y S. GONZALEZ. (1972). Notas sobre uredinales chilenos Sydowia 26: 1-25.

-2. (1975). Notas sobre uredinales chilenos III: Nuevos hospederos para tres especies ya establecidas. Agro Sur 3: $63-66$.

SAVILE, D.B.O. (1979). Fungi as aids in higher plant classification. Bot. Rev. 45: 377-503.

SCHMITHUSEN, J. (1968). Allgemeine Vegetationsgeographie. Walter de Gruyter, Berlin, 463 p.

SCHUSTER, R.M. (1970). Plate tectonics and its bearing on the geographical origin and dispersal of anglosperms. In: C.B. beck (ed.) origin and earty evolution of angiosperms. Columbia Univ. Press: 48-138.

SHAW III, C.G. (1976). Rust on Phyllocladus trichomanoides - the first recorded on a member of the Podocarpaceac. Trans. Br. mycol. Soc. 67:506-509.

STEENIS, C.G.G.J. van (1962). The land-bridge theory in Botany. Blumea 11: 235-542.

- (1971). Nothofagus, key genus of plant geography, in time and space, living and fossil, ecology and phylogeny. Blumea 19:65-98. 